RESEARCH ARTICLE

\title{
Standardization of Pellet size for Mechanized Sowing in Foxtail Millet (Setaria italica)
}

\author{
Rajeshwari ${ }^{1}$ M, Renganayaki ${ }^{1}$ P.R, Vanitha ${ }^{1} \mathbf{C}$ and Ravikesavan $\mathbf{R}^{\mathbf{2}}$ \\ 1*Department of Seed Science and Technology Tamilnadu Agricultural University, Coimbatore -641 003. \\ 2 Department of Millets Tamilnadu Agricultural University, Coimbatore -641003.
}

Received : $10^{\text {th }}$ June, 2020

Revised : $26^{\text {th }}$ June, 2020

Revised : $14^{\text {th }}$ July, 2020

Accepted : $04^{\text {th }}$ August, 2020

\begin{abstract}
The experiment was conducted at Department of Seed Science and Technology, Coimbatore during 2019-20 to standardize the pellet size for mechanized sowing in foxtail millet. The seeds of foxtail millet (Setaria italica) were circumscribed by small amount of filler materials and adhesive to produce a globular unit of size and also supply nutrient to the plant. Pellet size in terms of seed size has been standardized by using TNAU pelleting powder as filler material and gum acacia as adhesive to suite the requirement of air assisted seed drill for precision sowing with minimum seed rate. Results showed that the pellet size of $3.1 \mathrm{~mm}$ was found to be optimum for mechanized sowing with seed drill and 11 layers of coating with filler material increases the seed size from 0.8 to $3.1 \mathrm{~mm}$. The seeds coated to 11 layers have recorded maximum germination (87\%), root length(12.7 $\mathrm{cm})$, shoot length $(6.3 \mathrm{~cm})$, vigour index (1656) with high speed of germination (6.5) at laboratory condition.
\end{abstract}

Keywords: Small millets; Seed pelleting; Pellet size; Mechanical sowing; Seed quality

\section{INTRODUCTION}

Millets plays a major role in food security and human nutrition by providing minerals and vitamins. Foxtail millet (Setaria italica) is one of the important millet mostly cultivated in arid and semi arid regions of Asia and other parts of the world. It is rich in thiamine, calcium, dietary fiber and low in fat. However farmers mostly raised the crop under rainfed condition and marginal lands with minimum care.

The main problem in millets is their seed size; because of small size, a large quantity of seeds are being wasted during sowing and also needs a substantial number of labourers for sowing and thining. These problems can be addressed by mechanical sowing using seed drills. Since most of the millets seeds are smaller in size, it is not amenable for mechanical sowing; and therefore the size of the seeds has to be increased to match with the hole size in the seed drill. Seed pelleting is one of the seed enhancement techniques in which the seeds are coated with inert/nutrient material with the help of adhesive which will increase the seed size to the required level. Pelleting is mostly practiced in small (Halmer,2003) and irregular shaped seeds for easy handling and also helps in mechanized sowing. The pelleting material serves as an appropriate carrier for biofeertilizers, insecticides, fungicides and nutrients (Dunning et al., 1985 and Chayadevi., 2017). Pelleting is also helps to provide uniform plant spacing by mechanized sowing. Sowing of pelleted seed offers protection from rodents, birds and insects (Manjunath et.al. 2009). Seeds pelleted with nutrients improve the initial growth and emergence of the seedling (Roos et al., 1979). With the objective of optimization of seed pellet size in foxtail millet for mechanized sowing, a study was taken up at Department of Seed Science and Technology, Coimbatore during 2019-20.

\section{MATERIAL AND METHODS \\ MATERIALS}

Foxtail millet $\mathrm{CO}(\mathrm{Te}) 7$ seed with 92 per cent germination and $\mathbf{1 1 . 5}$ per cent seed moisture content was obtained from Centre of Excellence for Millets (CEM), Athiyanthal, Thiruvannamalai. For pelleting the seeds, TNAU Pelleting mixture was used as inert material and gum acacia @ $4 \%$ was used as adhesive. The gum acacia $4 \%$ was prepared by mixing $40 \mathrm{~g}$ powder in 1 litre of water.

\section{METHODS}

\section{Seed pelleting}

While pelleting, the seeds were spreaded in a thin layer and sprayed with adhesive (4\%) over the seeds. Wet seeds were transferred to a container 
and measured quantity of pelleting mixture was added for each layer of pellet as detailed below (Table 1) and the seeds were pelleted upto 9 layers $\left(S_{1}\right), 11$ layers $\left(S_{2}\right)$ and 13 layers $\left(S_{3}\right)$. Between each step, gum was sprayed for effective coating of pelleting mixture

While pelelting, the container was rotated vigourously to avoid the multi and pseudo pellets and to facilitate uniform distribution of pelleting mixture. After completiong of pelleting process, the pelleted seeds were dried in hot air oven maiantained at $40^{\circ} \mathrm{C}$ for $2 \mathrm{hr}$ to increase the compactness. Unpelleted seeds served as control.

The size of pelleted and unpelleted seeds was measured by using vernier calliper. Germination test for pelleted and unpelleted seeds was carried out in paper medium using 400 seeds for each treatment with four replications @ 100 seeds per replication. The paper towels were kept in a germination room maintained at a temperature of $25 \pm 1^{\circ} \mathrm{C}$ and $\mathrm{RH}$ of $96 \pm 2$ percent with diffused light (approx. $10 \mathrm{~h}$ ) during the day. Final count on normal seedlings was recorded on tenth day and percent germination was computed. All normal seedling were measured for root length (between collar region and tip of primary root ), shoot length (from collar region to tip of leave) and expressed in $\mathrm{cm}$. The vigour index value was calculated as per Abdul Bakiand Anderson, 1973 and expressed in whole number. For determination of dry weight, the seedlings were dried in a hot air oven maintained at $85^{\circ} \mathrm{C}$ for $48 \mathrm{~h}$ and kept in a desiccator for $30 \mathrm{~min}$ and weighed in an electronic digital balance and mean dry weight was arrived and expressed as $\mathrm{mg} 10$ seedlings ${ }^{-1}$.The speed of germination was calculated by the procedure given by Maguire, (1962); the protrusion of plumule from pelleted seeds were counted daily from sowing up to final count day and calculated the speed of germination as per the formula .

Speed of germination $=X_{1} X_{2}-X_{1_{+}} X_{n}-X_{n-1}$

$\overline{Y_{1}} \quad \overline{Y_{2}} \quad \overline{Y_{n}}$

$X_{1}-$ Number of seeds germinated at first count
$X_{2}$ - Number of seeds germinated at second count

$X_{n}$ - Number of seeds germinated on $n$th day

$Y_{1}$ - Number of days from sowing to first count

$Y_{2}$ - Number of days from sowing to second count

$Y_{n}$ - Number of days from sowing to $n$th count

Dissolution rate of pelleted seeds was calculated by dropping ten randomly selected pelleted seeds in water and time taken to dissolve the pelleted material was recorded (Dogan et al.,2005).

Similarly pelletization efficiency was calculated as per Baladhiya et al., (2011).

\begin{tabular}{|c|c|}
\hline \multirow{2}{*}{$\begin{array}{l}\text { Pelletization } \\
\text { efficiency }(\%)=\end{array}$} & $\begin{array}{l}\text { Number of pellets } \\
\text { containing seed }\end{array}$ \\
\hline & $\begin{array}{c}\text { Number of pellets } \\
\text { prepared }\end{array}$ \\
\hline
\end{tabular}

For fragmentation test, 100 pellets in two replications were taken in a plastic bag and vigorous manual shaking was given for one minute. After that, the number of broken and cracked pellets were recorded (Tamilselvi, 2017).

Double pellet ie a pellet containing two seeds and pseudo pellet ie a pellet without seed were counted using 400 seeds in four replications each with 100 seeds.

\section{STATISCAL ANALYSIS AND METHODOLOGY USED}

The data observed from laboratory experiments were analysed statiscally for $\mathrm{F}$ test of significance adapting the methods described by Panse and Sukatme (1985) whenever necessary value in the percent data was transformed to angular transformation and at $5 \%$ level critical difference was computed.

\section{RESULTS AND DISCUSSION}

\section{Physical properties of pellet}

The seeds pelleted to different layers were examined for their physical properties and suitability for germination under laboratory condiciton. The results are presented herunder.

Table 1. Details of seed pelleting process (for $15 \mathrm{~g}$ of seeds)

\begin{tabular}{|c|c|c|c|c|c|}
\hline \multirow{2}{*}{$\begin{array}{l}\text { Pelleting powder used } \\
\text { per layer (g) }\end{array}$} & \multirow{2}{*}{ No.of layers } & \multirow{2}{*}{$\begin{array}{l}\text { Total Quantity of } \\
\text { pelleting powder used } \\
\text { (g) to coat } 15 \mathrm{~g} \text { of } \\
\text { seeds }\end{array}$} & \multicolumn{2}{|c|}{ Cumulative } & \multirow{2}{*}{$\begin{array}{l}\text { Size of the pelleted } \\
\text { seed }(\mathrm{mm})\end{array}$} \\
\hline & & & Layers (No.) & $\begin{array}{l}\text { Pelelt mixture } \\
\text { requirement (g) }\end{array}$ & \\
\hline 0.20 & 2 & 0.40 & 2 & 0.40 & 0.20 \\
\hline 0.40 & 2 & 0.80 & 4 & 1.2 & 0.30 \\
\hline 0.60 & 2 & 1.20 & 6 & 2.4 & 0.26 \\
\hline 0.70 & 3 & 2.10 & $9\left(S_{1}\right)$ & 4.5 & 2.52 \\
\hline 1.25 & 2 & 2.50 & $11\left(S_{2}\right)$ & 7.0 & 3.12 \\
\hline 1.75 & 2 & 3.50 & $13\left(S_{3}\right)$ & 10.5 & 3.45 \\
\hline
\end{tabular}

$107|7-9| 2$ 
The hundred seed weight of pelleted seeds was maximum than unpelleted seeds because of adding filler materials. $\mathrm{S}_{3}$ (13 layers of pelelting) showed maximum 100 seed weight (3.0g) than other two layers $\left(\mathrm{S}_{1}-1.4 \mathrm{~g}\right.$ and $\left.\mathrm{S}_{2} 2.5 \mathrm{~g}\right)$. The results for length of pellet also showed the same trend. In which the maximum length $(3.56 \mathrm{~cm})$ was recorded in $\mathrm{S}_{2}(11$ layers ) but $\mathrm{S}_{0}$ (control) recorded minimum length $(1.56 \mathrm{~cm})$ (Figure 3).

Table 2. Effect of pelleting on physical properties of Foxtail millet seeds

\begin{tabular}{lrrrrrr}
\hline Pellet size & $\begin{array}{r}\text { Size of the } \\
\text { seed/pellet } \\
(\mathbf{m m})\end{array}$ & $\begin{array}{r}\text { 100 seed } \\
\text { weight }(\mathrm{g})\end{array}$ & $\begin{array}{r}\text { Length of } \\
\text { seed/pellet } \\
(\mathbf{m m})\end{array}$ & $\begin{array}{r}\text { \% of } \\
\text { increase } \\
\text { over control }\end{array}$ & $\begin{array}{r}\text { Breadth } \\
(\mathbf{m m})\end{array}$ & $\begin{array}{r}\text { \% of } \\
\text { increase } \\
\text { over control }\end{array}$ \\
\hline Control (SO) & 1.5 & 0.23 & 1.56 & - & 1.71 & - \\
9 layers (S1 -2.5 mm) & 2.5 & 1.42 & 2.17 & 39 & 2.24 & 31 \\
11 Layers (S2 -3.1 mm) & 3.1 & 2.50 & 3.56 & 98 & 3.30 & 92 \\
13 Layers (S3 -3.4 mm) & 3.4 & 3.02 & 3.42 & 119 & 3.52 & 104 \\
Mean & 2.62 & 1.79 & 2.67 & 85.33 & 2.69 & 75.66 \\
S Ed. & 0.042 & 0.004 & 0.003 & 1.26 & 0.005 & 0.55 \\
CD (P= 0.05) & 0.093 & 0.009 & 0.007 & 2.90 & 0.01 & 1.26
\end{tabular}

The percentage increase in length of pelletes was higher in $\mathrm{S}_{2}(98 \%)$ than $\mathrm{S}_{1}(39 \%)$. The maximum breadth of seed was recorded in $S_{3}(3.52 \mathrm{~cm})$ followed by $\mathrm{S}_{2}(3.30 \mathrm{~cm})$ and the least breadth was observed in unpelleted control $\left(\mathrm{S}_{0}-1.71 \mathrm{~cm}\right.$ ) (Figure 4). The percentage increase in breadth of pelletes in pellet size of $\mathrm{S}_{3}$ was higher (104\%) than $\mathrm{S}_{1}(31 \%)$ (Table 2).

Table 3. Effect of seed pelleting on Fragmentation, pelletization efficiency, double seeds and dissolution rate

\begin{tabular}{|c|c|c|c|c|c|c|}
\hline \multirow{3}{*}{ No.of layers } & \multicolumn{6}{|c|}{ Foxtail millet } \\
\hline & \multirow[b]{2}{*}{ Fragmantation (\%) } & \multirow{2}{*}{$\begin{array}{l}\text { Pelletization } \\
\text { efficiency (\%) }\end{array}$} & \multirow{2}{*}{$\begin{array}{c}\text { Double } \\
\text { seeds } \\
(\%)\end{array}$} & \multirow{2}{*}{$\begin{array}{l}\text { Pseudo } \\
\text { pellet (\%) }\end{array}$} & \multicolumn{2}{|c|}{ Time taken for dissolution } \\
\hline & & & & & $\begin{array}{l}\text { Initiation } \\
\text { (min) }\end{array}$ & $\begin{array}{l}\text { Completion } \\
\text { (min) }\end{array}$ \\
\hline Control (SO) & - & - & - & - & - & - \\
\hline 9 layers $\left(\mathrm{S}_{1}-2.5 \mathrm{~mm}\right)$ & 0.3 & 0 & 1.07 & 0 & 2.0 & 5.4 \\
\hline 11 Layers $\left(\mathrm{S}_{2}-3.1 \mathrm{~mm}\right)$ & 0.2 & 0 & 1.0 & 0 & 3.1 & 6.3 \\
\hline 13 Layers $\left(\mathrm{S}_{3}-3.4 \mathrm{~mm}\right)$ & 0.5 & 0 & 0.8 & 0 & 6.1 & 6.5 \\
\hline Mean & 0.33 & 0 & 0.95 & 0 & 3.73 & 6.06 \\
\hline S Ed. & 0.07 & - & 0.002 & - & 0.003 & 0.002 \\
\hline$C D(P=0.05)$ & 0.17 & - & 0.005 & - & 0.006 & 0.005 \\
\hline
\end{tabular}

The increase in physical properties of pelleted seeds viz.,pellet size, weight, length and breadth of $S_{3}, S_{2}$ and $S_{1}$ over unpelleted control was due to addition of $10.5 \mathrm{~g}$ of pelleting mixture to $15 \mathrm{~g}$ of seeds. Among the three different pellets, $\mathrm{S}_{1}$ had taken lesser time to dissolute (5.4 $\mathrm{min}$ ) when compared to $\mathrm{S}_{3}(6.5 \mathrm{~min})$.

Table 4. Seed quality parameters of pelleted seeds in Foxtail millet

\begin{tabular}{|c|c|c|c|c|c|c|}
\hline Pellet size $(\mathrm{mm})$ & $\begin{array}{r}\text { Speed of } \\
\text { germination }\end{array}$ & $\begin{array}{r}\text { Germination } \\
(\%)\end{array}$ & $\begin{array}{r}\text { Root length } \\
(\mathrm{cm})\end{array}$ & $\begin{array}{r}\text { Shoot length } \\
(\mathrm{cm})\end{array}$ & Vigour index & $\begin{array}{r}\text { Dry matter } \\
\text { production } \\
\text { (mg/10 } \\
\text { seedlings) }\end{array}$ \\
\hline Control $\left(\mathrm{S}_{0}\right)$ & 7.3 & $89(70.60)$ & 8.2 & 6.0 & 1289 & 40.37 \\
\hline 9 layers $\left(\mathrm{S}_{1}-2.5 \mathrm{~mm}\right)$ & 6.8 & $88(69.71)$ & 12.4 & 6.0 & 1621 & 40.43 \\
\hline 11 Layers $\left(\mathrm{S}_{2}-3.1 \mathrm{~mm}\right)$ & 6.5 & $87(68.84)$ & 12.7 & 6.3 & 1656 & 54.78 \\
\hline 13 Layers $\left(\mathrm{S}_{3}-3.4 \mathrm{~mm}\right)$ & 6.4 & $87(68.84)$ & 11.4 & 5.5 & 1405 & 54.76 \\
\hline Mean & 9.0 & 87.75 & 11.17 & 5.95 & 1492.75 & 47.83 \\
\hline S Ed. & 0.09 & 1.08 & 0.21 & 0.10 & 10.8 & 0.703 \\
\hline$C D(P=0.05)$ & 0.18 & 2.37 & 0.43 & 0.21 & 23.8 & 1.54 \\
\hline
\end{tabular}


Due to more number of layers and addition of $3.5 \mathrm{~g}$ of pelelting mixture, S3 might have taken longer duration for dissolution. Dogan et al.,(2005), reported that massive diameter of pelleted seeds causes the less dissolution rate and imbibitions of water (Table 3) and the author opined that the low rate of imbibitions might be the reason for longer germination period and less speed of germination.

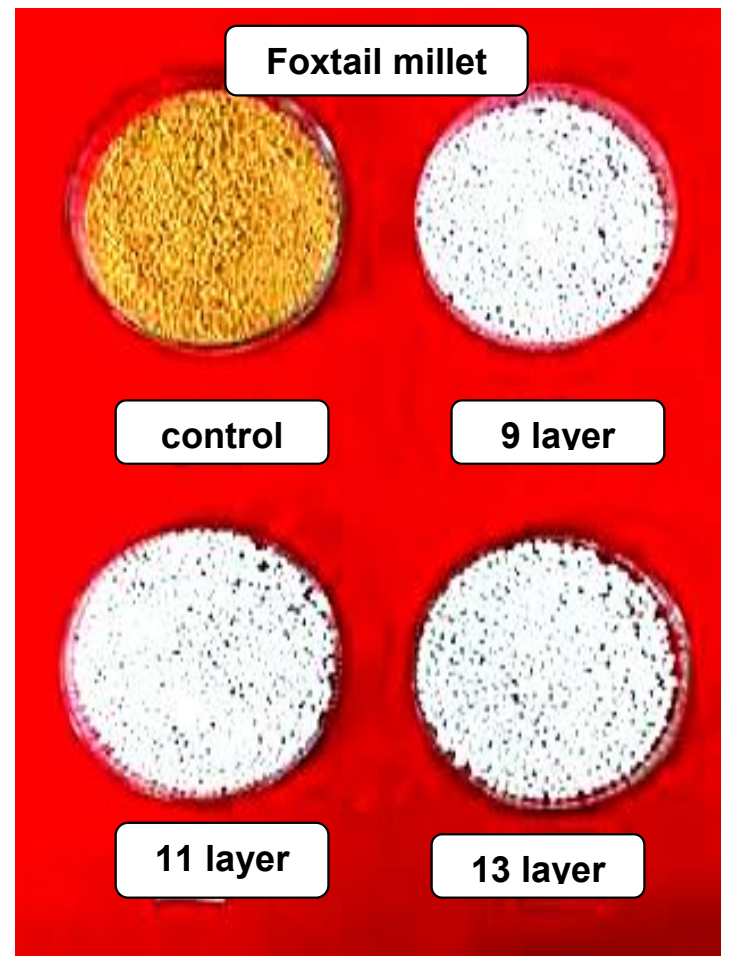

Figure.1 Different size of pelleted foxtail millet seeds

In fragmentation test, the maximum broken and cracked pellets was observed in $\mathrm{S}_{3}(6.1 \%)$ followed by $\mathrm{S}_{2}$ (3.1\%) and least was observed in $\mathrm{S}_{1}(2.0 \%)$. No pseudo pellet was observed in all the three pellets which showed high pelleting efficiency in foxtail millet. The maximum double seed per cent in single pellet was noticed in $\mathrm{S}_{2}(1.0 \%)$ but it was minimum in $\mathrm{S}_{3}(0.8 \%)$ (Table 3$)$.

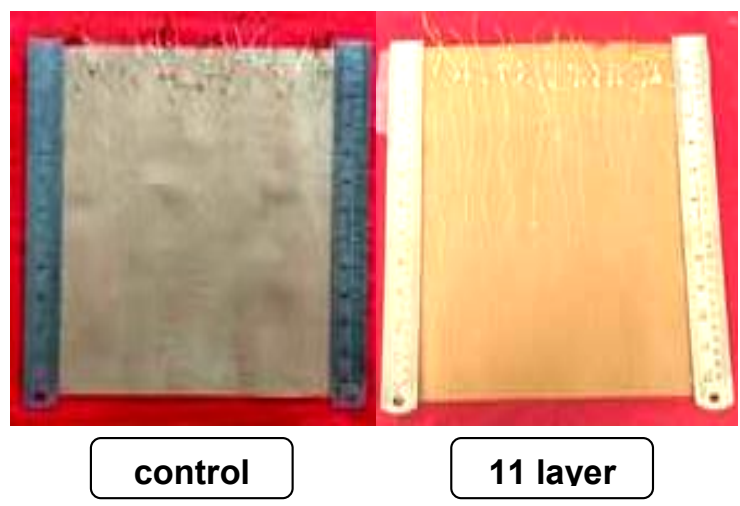

Figure 2.Seedling vigour of foxtail millet seeds
Irrespective of size of pellets, significant difference was observed in speed of germination due to pelleting over unpelleted seeds. Among the pellet size, $S_{1}$ recorded maximum speed of germination (6.8) over $S_{3}$ (6.4.) In case of seed germination percentage, $\mathrm{S}_{0}$ (unpelleted seeds) showed maximum germination (89\%) which was on par with $\mathrm{S}_{1}$ (88\%). The maximum root length $\left(12.7 \mathrm{~cm}\right.$ ) was observed in $\mathrm{S}_{2}$ (11 layers of pelelting) which was on par with $S_{1}(12.4 \mathrm{~cm})$ and the minimum root length was observed in control $\left(\mathrm{S}_{0}\right)(8.2 \mathrm{~cm})$ (Table 4).

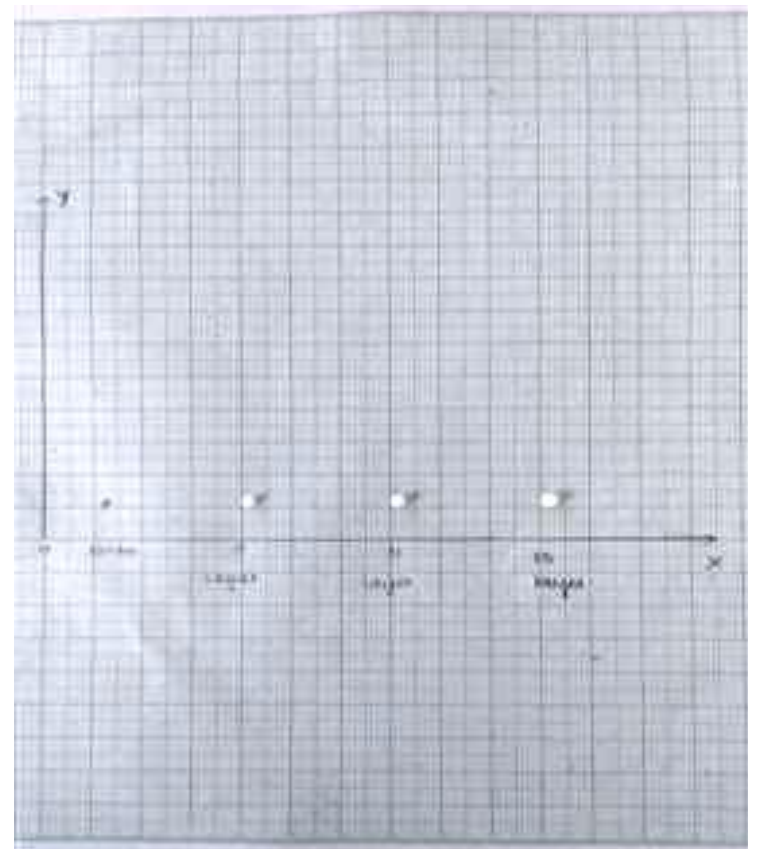

Figure 3. Size of pellets in graphical representation

Pelleting of seeds with pellet mixture may supplement with nutrients which might have caused the increased emergence and vigour of the seedling (Roos et al., 1979).The TNAU pelleting powder enhances the supply of nutrient to the rhizosphere region so pelleted seeds attain the maximum root length. Shoot length results betrayed that considerable difference was observed in unpelleted and pelleted seeds. The unpelleted seeds and pellet size of 9 layers $\left(\mathrm{S}_{1}\right)$ showed the same shoot length $(6.0 \mathrm{~cm})$ and the highest shoot length was observed in $S 2(6.3 \mathrm{~cm})$. The pelleted seeds showed significant difference in vigour index than unpelleted seeds. The highest vigour index was observed in $\mathrm{S}_{2}(1656)$ and minimum vigour index was observed in $S_{0}$ (1289) (Figure 2). The maximum dry matter production was observed in $\mathrm{S}_{2}$ (54.78 $\mathrm{mg}$ ) over unpelleted seeds (40.37 mg) (Table 4).

Based on the performence of the pelleted seeds (3.1 mm with 11 layers) in laboratory, a field trial was taken up in field number 37 (F) at Department of Seed Science and Technology, TNAU, Coimbator to assess the feasibility of sowing pelleted seeds 
through mechanized sowing using air assisted seed drill with hole size of $3.0 \mathrm{~mm}-3.5 \mathrm{~mm}$. Both pelleted and unpelleted seeds were sown in an area of 0.2

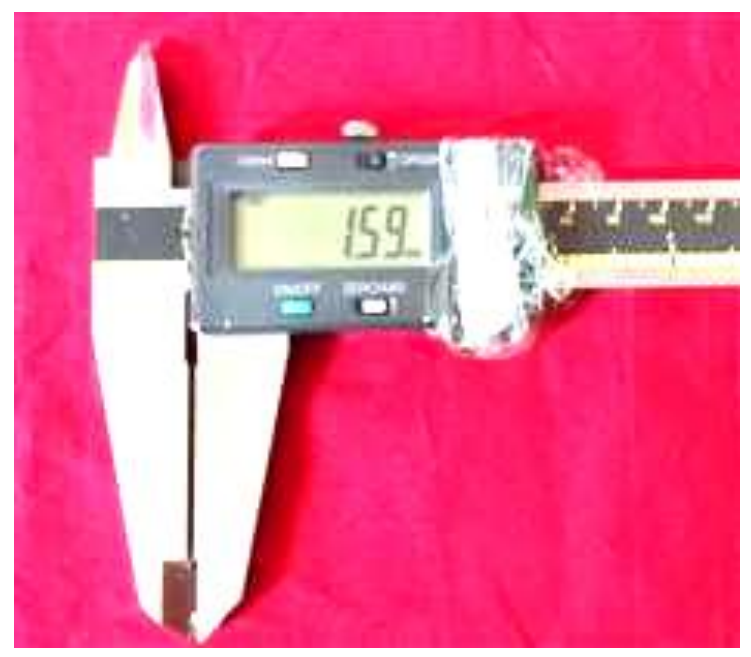

\section{Unpelleted}

Figure 4. Size of pellet measured in Vernier calliper

It was also observed that pelleted seeds recorded maximum field establishment (100\%) with single seedlings per hill with improved vigour.

\section{CONCLUSION}

It is concluded that pellet size of 11 layers $\left(\mathrm{S}_{2}\right.$ $-3.1 \mathrm{~mm}$ ) recorded maximum germination, seedling quality characteristics, field emergence with high vigour, pelletization efficiency with uniform pellet size and reduced seed rate through mechanized sowing. Hence, the pellet size of $3.1 \mathrm{~mm}$ with 11 layers can be recommended as the optimum pellet size for mechanized sowing in foxtail millet seeds.

\section{REFERENCES}

Abdul-Baki, A.A. and J.D. Anderson. 1973. Vigour determination in soybean seeds by multiple criteria. Crop Sci., 13: 630 - 633.

Baladhiya, C.S., Doshi, J.S., \& Joshi, D.C. (2011). Influence of Pelleting on Lucerne (Medicago sativa L.) Seed. Journal of Agricultural Engineering, 48(4): 34-42.

Chaya devi, K. "Studies on the influence of seed pelleting on crop performance, seed yield and quality in french bean (Phaseolus vulgaris I.) cv., arka anoop"e." phd diss., University of Agricultural Sciences GKVK, Bangalore. ha each as non replicated trial. During sowing, it was obsrved that 40 per cent reduction in seed requirement in pelleted seeds $(6.0 \mathrm{~kg})$ over control (10.0 kg) per hectar.

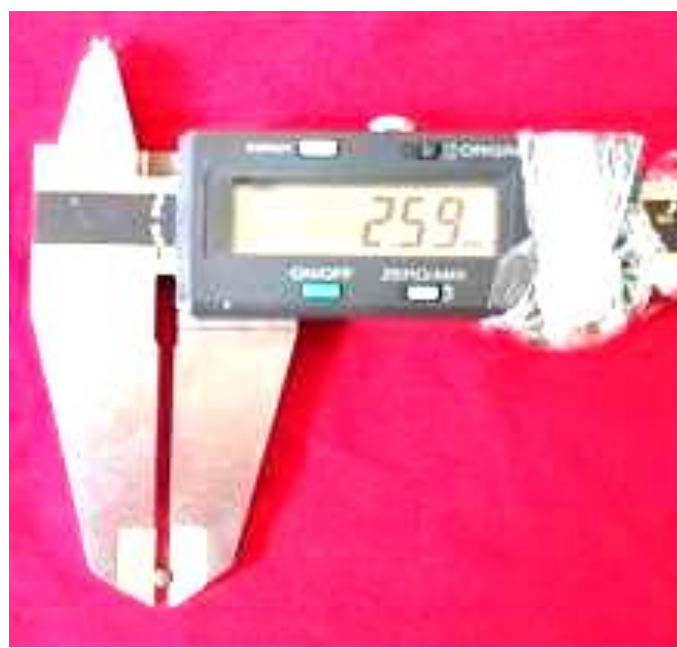

Pelleted

Dogan.T Aykas, E., Tuvay, N. H., \& Zeybek, A. (2005). A study on pelleting and planting sesame (Sesamum indicum L.) seeds. Asian Journal of Plant Sciences.

Dunning, W., J. Byford and M.J. Durant. 1985. Sugar beet seed treatment. In: monograph, 2(Ed. Jeffs, K. A.). Collaborative.Int. Pesticide Analytical Council.

Halmer,p.,2003 Enhancing seed performance for better yield and quality. Asian seeds plants Mater.,10:4-7

Maguire, J.D. (1962). Speed of germination-Aid in selection and evaluation for seedling emergence and vigor 1. Crop science, 2(2): 176-177.

Manjunath, S.N., V.K. Deshpande, O. Sridevi, D.S. Uppar, H.B. Babalad and S.L.Rao. 2009. Influence of seed pelleting on crop growth, seed yield and quality of paprika chilli (Capsicum annuum L.). Kar. J. Agric. Sci., 22(4): 762 - 764.

Panse, V.G., \& Sukhatme, P.V.(1985). Statistical methods for agricultural workers $2^{\text {nd }}$ Edition ICAR New Delhi.

Roos, E. 1979. Storage behaviour of pelleted, tabeleted taped lettuce seed. Hortic. Sci., 104(2):283- 288.

Tamilselvi P. (2017) Development of Multi row Seeder for Carrot. Unpublished Ph.D. thesis, Tamil Nadu Agricultural University, Coimbatore. 